\title{
Factors Affecting the Propensity to Create Budgetary Slack Evidence from Vietnamese Enterprises
}

\author{
TRINH HIEP THIEN \\ University of Economics - HCMC - trinhhiepthien@ueh.edu.vn
}

\section{ARTICLE INFO ABSTRACT}

Article history:

Received:

Aug. 82014

Received in revised form:

Sep. 222014

Accepted:

Dec. 302014

\section{Keywords:}

budgetary slack, budget participation, budget emphasis, nonfinancial managerial accounting information, human aspects of budgeting
Budgeting is widely advertised as an effective managerial accounting tool but has been criticized mainly for budgetary slack reason. The purpose of this article is therefore to empirically examine relationships between budget participation, budget emphasis, risk awareness, private knowledge and the propensity to create budgetary slack. This study also extends the previous research by testing the hypothesized effect of the nonfinancial managerial accounting information use on various factors associated with the propensity to create budgetary slack. A survey data from 243 Vietnamese enterprises was used to conduct a structural equation modeling analysis. The results indicate that budget participation and budget emphasis incrementally affect the propensity to create budgetary slack while nonfinancial managerial accounting information is fairly useful to limit human aspects of budgeting. In addition, no correlation between private knowledge and creation of budgetary slack by subordinates was found. Once again, the results of this research confirm the effects of human factors in budgeting, which measured in a Vietnamese business environment and extended the understanding of the role of nonfinancial managerial accounting information in improving the budgeting process. 


\section{Introduction}

A company must have strategies as the direction and scope of an organization over the long term, which specifies how an organization matches its own capabilities with the opportunities in marketplace to accomplish its objectives. Strategies are expressed through long-run budgets and operating plans which are expressed via short-run budgets. It is clear that budgeting is a common managerial accounting tool for implementing strategy. Budgets turn managers' perspectives forward as well as aid in planning and controlling the actions. They also provide measures of financial results a company expects from its planned activities. However, budgets are often strongly criticized by practitioners and academics. Although budgeting is too often thought of as a mechanical tool, the budgeting techniques themselves are free of emotion; thus, primarily used to emphasize that human factors are likely to negatively affect the budgeting process (Horngren, Datar, Foster, Rajan \& Ittner, 2012). As a consequence, the key drawback of budgeting is from budgetary slack. Budgetary slack is a real world problem frequently faced by financial professionals and managers at various organizational levels. Budgets containing slack are often less than optimally motivating because the efforts of the employees in the organization may decline when achievement of an organization's goal is assured. Slack creation also appears costly and less than fair to the users of the budget submissions e.g. upper management (Simons, 2000). The users will rely on the information in the budget to make investment, resource allocation, and performance evaluation decisions that will become distorted. Due to these unfavorable impacts, understanding the proposed relationships between factors such as budget participation, budget emphasis, private knowledge, the use of nonfinancial managerial accounting information and budgetary slack may help managers and financial professionals to reduce budgetary slack in the future. Particularly, one of the key purposes in this research is to confirm the role of nonfinancial managerial accounting information in constraining with the phenomenon of budgetary slack because nonfinancial managerial accounting information will bring managers a wide scope of information to set up budgets as well as to design performance evaluation multi-indicators in spite of depending on the only budgetary targets for both planning and performance evaluation.

In the following section, this paper demonstrates a research framework describing the conceptual model and a set of testable hypotheses. In the discussion of the research methodology, the sample and construct measurement are detailed. Next, it also 
summarizes the results of structural equation modeling analysis before identifying this study's contribution, presenting managerial recommendations and suggesting some avenues for further research.

\section{Literature review}

The origin of budgetary slack theory traces to the "scientific management" era when Taylor (1911) discusses how production workers often do not work to their best capacity. In Whyte's (1955) study of factory work standard, Whyte concludes that factory workers believed that if they worked up to their full capacity, management would use new-found capacity knowledge against them. Work standard will be then replaced at the higher level which either wages or extra bonus earned may not compensate labor consumption. Up to 1963, Cyert and March search the budgetary slack theory focusing on managers instead of factory floor workers. Cyert and March (1963) suggest that managers bargain for extra resources in their plans as budgetary slack to protect themselves from environmental uncertainties. According to literature review, the concept of budgetary slack has shown significant development in behavioral accounting disciplines for a long time. It starts from 1900s and is clearly presented when Cyert and March (1963) defines budgetary slack as the differences between "the total resources available to a firm and the total resources necessary to maintain the organization coalition". Young (1985) determines the concept of budgetary slack as either the amount of additional resources managers purposely construct in the budget or the amount by which they wittingly understate productive capability. However, Young's definition, because of its focus on intent, has been difficult to operationalize (Hergert, 1999). After large pieces of relevant research are reviewed, Schiff and Lewin's definition is opted to use in this paper. It is defined that budgetary slack describes the practice of underestimating budgeted revenues, or overestimating budgeted costs, to make budgetary targets more easily achievable (Schiff \& Lewin, 1970).

On the other hand, it is flawed as it fails to discuss budgetary slack theory without mentioning agency theory because agency theory influenced the development of budgetary slack theory. Budgeting is effective when lower-level managers participate and meaningfully engage in the budgeting process. Thus, agency theory is a condition where parties with different goals in an organization i.e. owners vs. managers or senior managers vs. lower-level managers need to cooperate. Each party's participation 
requires honest communication about the business from subordinates and lower-level managers to their bosses. However, conflicting or dysfunctional behavior will occasionally occur, particularly when agents will act in the way which budgetary information might be manipulated to their principles owing to being motivated by each party's different goals. For example, line managers are also unlikely to be fully honest in their budget communication if top management mechanically institutes across-theboard cost reductions in the face of projected revenue reductions. In addition, asymmetric information theory also explains the propensity to create budgetary slack. Asymmetric information theory describes situations when a subordinate manager possess information about how to perform his or her job responsibilities which are not known to his or her immediate superior (Hergert, 1999). At times, subordinates may try to "play games" and build in budgetary slack.

Budgetary slack researchers in the world have identified several variables they believe their influences on the creation of budgetary slack. In contrast with the worldwide trend, Vietnam clearly lacks not only the necessary research of the determinants affecting the propensity to create budgetary slack but also the behavioral research in the field of managerial accounting. Only the basis of worldwide papers reviewed, hence, Table 1 summarizes the determinants identified in the prior pieces of research and the relationship between determinants and the concept of budgetary slack.

\section{Hypotheses}

\subsection{Budget participation and budgetary slack}

As mentioned above, budgeting is most effective with the active participation of lower-level managers in budgeting process. Participation adds credibility to the budgeting process and creates greater commitment and accountability toward the budget. However, participation requires "fair and objective" communication about the business from subordinates and lower-level managers to their hierarchies. Also, participation provides subordinates with an opportunity to build budgetary slack into their standards of performance. Of course, participation in the budgeting process is an essential precondition to being able to incorporate slack into budgets. Young (1985) finds that subordinates, when given the opportunity to participate in the budgeting process, build more slack into their budgets. Unlike Young (1985), Dunk (1990) suggests that since organizations of the future probably become more participative in functional 


\section{Table 1}

Determinants affecting budgetary slack and researchers

\begin{tabular}{llc}
\hline Determinant & Proposed by & Affirmed Sign \\
\hline $\begin{array}{l}\text { Degree of participation in budgeting } \\
\text { process }\end{array}$ & $\begin{array}{l}\text { Young (1985), Yuen (2007) } \\
\text { Onsi and Mohamed (1973); Dunk } \\
(1990)\end{array}$ & + \\
Budget emphasis & $\begin{array}{l}\text { Onsi and Mohamed (1973); Dunk } \\
(1993) ; \text { Hoque and Brosnan (2007) }\end{array}$ & + \\
Risk awareness & $\begin{array}{l}\text { Duncan (1972); Young (1985); } \\
\text { Gélinas (2007) }\end{array}$ & + \\
Private knowledge & Young (1985); Dunk (1993); \\
& Hergert (1999); Jermias (2011) & + \\
Level of commitment to & Nouri (1996); Stevens (2002) \\
organization & & + \\
Social pressure from peers & Onsi and Mohamed (1973) \\
Cultural factors & Ueno and Sekaran (1994); Douglas & + \\
& and Wier (2005) \\
\hline
\end{tabular}

relationships and because employees' level of identification with their profession is highly increasing, budget participants' propensity to create budgetary slack will be low. Nevertheless, business environment in Vietnam is unlikely satisfactory with Dunk's (1990) initial assumptions of the employees' professionals and the organization structure in flat form, so Dunk's (1990) conclusion is predicted to be unsuitable with Vietnamese business environment. On the basis of this discussion, the first hypothesis is formulated in order to predict that the level of budget participation likely causes the tendency of creating budgetary slack similar to Young's (1985) conclusion.

$\mathrm{H}_{1}$ : Budget participation is positively associated with the propensity to create budgetary slack.

\subsection{Risk awareness and budget emphasis and budgetary slack}

The perception of uncertainty influences managers' attitude on risk management. It is the perception of uncertainty rather than the actual uncertainty that affects the decision 
making (Lawrence \& Lorsch, 1967). When the environment becomes less favorable or highly unpredictable, higher-level management often organize management control system by using result controls which forces lower-level management or subordinates to respond spontaneously to the changing environment to ensure the attainment of budgetary targets (Mason, 1985). Strictly speaking, when facing the turbulent business environment existing risks and uncertainties, managers will emphasize the role of budgets to control the output. As a result, lower-level management would tend to feel pressure to meet budgets as upper management emphasizes budgetary targets as control tools. Increased emphasis by superiors on meeting budgets, will increase subordinates' propensity to create budgetary slack (Gary, 1997). On this reasoning, the second and third hypotheses are formulated as follows:

$\mathrm{H}_{2}$ : Greater risk awareness is positively associated with the degree of budget emphasis.

$\mathrm{H}_{3}$ : Budget emphasis is positively associated with the propensity to create budgetary slack.

\subsection{Private knowledge and budgetary slack}

Following the asymmetric information theory relevant to the degree of private knowledge held by subordinates, Dunk (1993) and Hergert (1999) hypothesize that when participation, emphasis on meeting budgets, and private knowledge are all high, slack will be higher. On the other hand, Pendergast (1997) finds an inverse relationship between the degree of understanding held by higher level managers about the operational side of the business and the amount of budgetary slack tendencies exhibited by lower level managers. Thus, the hypothesis tested by Dunk (1993) and Hergert (1999) will be re-examined due to the circumstances of Vietnamese enterprises in this article.

$\mathrm{H}_{4}$ : The degree of private knowledge has a positive effect on the propensity to create budgetary slack.

3.4. Risk awareness and the use of nonfinancial managerial accounting information and budgetary slack

Managerial accountants divide managerial accounting information into two broad categories: financial and nonfinancial information. Financial information is outcomes that are measured in numerical terms and expressed in monetary terms. Other information is nonfinancial; they can be measured numerically or not, but they are not 
expressed in monetary terms. Reduction in new product development time for a manufacturing company and the percentage of on-time flight arrivals for an airline company are examples of nonfinancial managerial accounting information. Planning or decision making requires management to assess the risk. When financial information is difficultly used to measure and to manage risks, nonfinancial measures can be used by management to analyze and assess risk. Kaplan and Norton (2001) encourage the use of a balanced scorecard to provide a broad range of both financial and nonfinancial measures designed to reflect the complexity and diversity of business circumstances as an approach to provide information to management assisting in strategic policy formulation and achievement. Consistent with this type of research, Srinivasan, Sayrak, and Nagarajan (2004) provide empirical evidence to show that mandatory use of nonfinancial managerial accounting information for the airline industry has explanatory powers beyond financial information for managing business process risk, information risk, and external or environmental risk. Another line of study focuses on the association between nonfinancial managerial accounting information and competitive pressure or strategic planning, Chow and Stede (2006) find that nonfinancial information about employee satisfaction in a sales department is generally a leading indicator of financial performance or customer satisfaction. From the evidence of prior research, the fifth hypothesis is built to test the relationship:

$\mathrm{H}_{5}$ : Risk awareness is positively associated with the use of nonfinancial managerial accounting information.

According to Duncan (1972), avoiding uncertainty motivates managers to create slack, as a consequence, the amount of slack that managers require to control for uncertainty depends on the degree of risk awareness. However, Horngren et al. (2012) proved that the use of nonfinancial managerial accounting information is likely to decrease managers' anxiety about risk and uncertainty because they strongly believe that their decisions made on the inputs are effective enough on both aspects of the quantity and quality of information. Mason (1985) concludes that managers in complex and uncertain environments should use more nonfinancial information such as that produced by a strategic management accounting system. Companies might reduce slack if they found better ways to detect it such as "investing in more and better information systems" (Merchant, 1985). Kirby, Alison, Rechelstein, Sen and Paik (1991) find no reason for managers with perfect information to have any budgetary slack. Following the 
relationship bridged between risk awareness and the use of non-financial managerial accounting and budgetary slack, the author posits:

$\mathrm{H}_{6}$ : The use of nonfinancial managerial accounting information has a decreasing incremental effect on the propensity to create budgetary slack.

This paper tests the correlation of factors attributed to the managerial process; thus, the factors attributed to culture or personal identification are omitted in the conceptual model although these were tested in the worldwide research as introduced in the part of theoretical background. Moreover, due to the limitation on resources to conduct a survey, the author has not employed a multi-national or multi-organization research to evaluate the differences of cultural dimensions affecting the tendency to create budgetary slack. As a result, the conceptual model for the research is finalized as illustrated in Figure 1. In this model, risk awareness, budget participation and private knowledge play the role as independent variables; the use of nonfinancial managerial accounting information and budget emphasis are considered moderate variables whereas budgetary slack is a dependent variable.

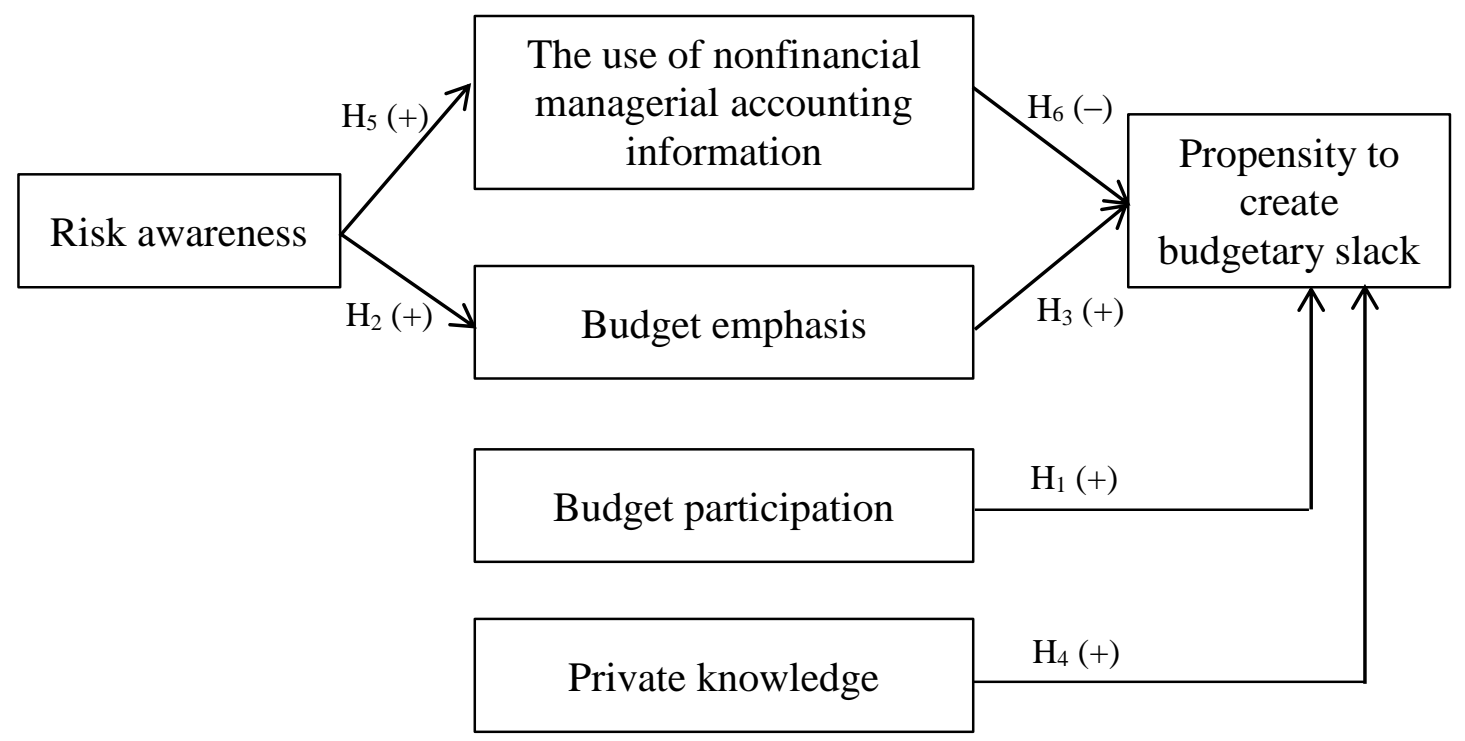

Fig. 1. Conceptual model 


\section{Methodology}

\subsection{Variables measurement}

To measure each construct in the conceptual model, variables including budget emphasis, risk awareness, and the use of nonfinancial managerial accounting information are anchored by five-point Likert scale, ranging from 1 (strongly disagree) to 5 (strongly agree). Moreover, this study measures budget participation through a seven-point Likert scale. A response of 1 indicates the lowest amount of participation, while a response of 7 indicates the greatest amount of participation on establishing budgetary targets. Particularly, the variable of private knowledge is also measured on a seven-point Likert scale but focusing on who knows more about the specifics of a manager's jobs or a department's capacity, the manager or his or her subordinates. 1scale reveales that a superior has much better information; 4-scale demonstrate that both have the same information, while 7-scale indicates that subordinates possess much better information. All observed variables of each concept are built based on the international prior research and modified to be appropriate with the respondents' culture and language (Table 2).

In this paper, Cronbach Alpha and Explanatory Factor Analysis are implemented to examine reliability and convergent validity of measurements through a pilot study with 160 samples. Cronbach Alpha Coefficients are 0.635-0.822 as being greater than 0.60 (Nunnally \& Burnstein, 1994), and all of item-total correlation coefficients are larger than 0.3; therefore, the whole of measurement scales are reliable to be utilized for EFA (Nunnally \& Burnstein, 1994). All factor loadings that are greater than a cut-off value of 0.50 are statistically significant. The EFA results also show that there are six factors with the Eigenvalue of more than 1.5 and the variance is $53.786 \%$. In addition, the KMO value of 0.738 and the very small Sig. value prove that EFA results are reliable. These measures, hence, are conceived appropriate for further analysis because they reveal an accepted validity and reliability in this study. Observed variables are arranged and named in accordance with a principle that one with its factor loading in favor of a dimension will be transferred to that dimension (Table 2). 


\section{Table 2}

EFA results and cronbach alpha of factors affecting the propensity to create budgetary slack






\section{Table 2 (continued)}

\begin{tabular}{|c|c|c|c|c|c|c|c|}
\hline & \multirow{2}{*}{ Item } & \multirow{2}{*}{ Source } & \multirow{2}{*}{$\begin{array}{l}\text { Corrected } \\
\text { Item- Total } \\
\text { Correlation }\end{array}$} & \multicolumn{4}{|c|}{ Factors loadings } \\
\hline & & & & PART & NOFI & SLACK & RISK EMPHS KNOW \\
\hline NOFI3 & Supplier perspective. & & .582 & & .650 & & \\
\hline NOFI1 & $\begin{array}{l}\text { The quantified likelihood } \\
\text { of future events occurring. }\end{array}$ & & .480 & & .532 & & \\
\hline SLACK2 & $\begin{array}{l}\text { Managers usually set two } \\
\text { types performance } \\
\text { standards: one between } \\
\text { themselves and their } \\
\text { subordinates for } \\
\text { management purpose; one } \\
\text { between themselves and } \\
\text { their superiors, to be safe. }\end{array}$ & & .579 & & & .793 & \\
\hline SLACK1 & $\begin{array}{l}\text { To protect themselves, } \\
\text { managers submit budget } \\
\text { requests that can safely be } \\
\text { attained. }\end{array}$ & $\begin{array}{l}\text { Onsi and } \\
\text { Mohamed } \\
(1973)\end{array}$ & .557 & & & .767 & \\
\hline SLACK3 & $\begin{array}{l}\text { In good business } \\
\text { conditions, superiors } \\
\text { should accept level of } \\
\text { excess resources } \\
\text { consumption in their } \\
\text { budgets. }\end{array}$ & & .513 & & & .696 & \\
\hline SLACK4 & $\begin{array}{l}\text { Padding budgets are } \\
\text { reasonable to do things } \\
\text { that cannot be officially } \\
\text { approved. }\end{array}$ & & .368 & & & .599 & \\
\hline RISK4 & $\begin{array}{l}\text { You feel that your } \\
\text { business is operating in } \\
\text { uncertainties. }\end{array}$ & & .506 & & & & .786 \\
\hline RISK2 & $\begin{array}{l}\text { You often think of } \\
\text { alternatives before } \\
\text { decision making. }\end{array}$ & Duncan & .560 & & & & .662 \\
\hline RISK3 & $\begin{array}{l}\text { You can determine what } \\
\text { the outcome of a decision } \\
\text { will be before it is made. }\end{array}$ & (1972) & .510 & & & & .616 \\
\hline RISK1 & $\begin{array}{l}\text { You often use information } \\
\text { which relates to possible } \\
\text { future events. }\end{array}$ & & .454 & & & & .512 \\
\hline
\end{tabular}


Table 2 (continued)

\begin{tabular}{|c|c|c|c|c|c|c|c|c|}
\hline & \multirow{2}{*}{ Item } & \multirow{2}{*}{ Source } & \multirow{2}{*}{$\begin{array}{c}\text { Corrected } \\
\text { Item- Total } \\
\text { Correlation }\end{array}$} & \multicolumn{5}{|c|}{ Factors loadings } \\
\hline & & & & PART & NOFI & SLACK RISK & EMPHS & KNOW \\
\hline EMPHS2 & $\begin{array}{l}\text { Senior managers should judge } \\
\text { lower-level managers' } \\
\text { performances on the basis of } \\
\text { attaining budgetary targets. }\end{array}$ & & .514 & & & & .735 & \\
\hline EMPHS1 & $\begin{array}{l}\text { Managers should initially } \\
\text { pressure their subordinates to } \\
\text { get things done for budgetary } \\
\text { targets. }\end{array}$ & Dunk & .499 & & & & .724 & \\
\hline EMPHS3 & $\begin{array}{l}\text { Managers should express } \\
\text { unsatisfactory attitude when } \\
\text { their subordinates cannot } \\
\text { achieve their budgetary } \\
\text { targets. }\end{array}$ & (1990) & .476 & & & & .709 & \\
\hline EMPHS4 & $\begin{array}{l}\text { Top management believes in } \\
\text { the merits of exerting pressure } \\
\text { on middle management. }\end{array}$ & & .441 & & & & .632 & \\
\hline KNOW2 & $\begin{array}{l}\text { In comparison with your } \\
\text { superior, who is better able to } \\
\text { assess the potential impacts of } \\
\text { external factors to your area } \\
\text { of responsibility? }\end{array}$ & & .443 & & & & & .679 \\
\hline KNOW4 & $\begin{array}{l}\text { In comparison with your } \\
\text { superior, who is more familiar } \\
\text { technically with the work of } \\
\text { your area of responsibility? }\end{array}$ & & .387 & & & & & .653 \\
\hline KNOW3 & $\begin{array}{l}\text { In comparison with your } \\
\text { superior, who has better } \\
\text { understanding of what can be } \\
\text { the objectives, responsibilities } \\
\text { in your department? }\end{array}$ & $\begin{array}{l}\text { Dunk } \\
\text { (1993) }\end{array}$ & .410 & & & & & .644 \\
\hline KNOW1 & $\begin{array}{l}\text { In comparison with your } \\
\text { direct report, who is in } \\
\text { possession of better } \\
\text { information regarding the } \\
\text { activities undertaken in your } \\
\text { area responsibility? }\end{array}$ & & .422 & & & & & .602 \\
\hline
\end{tabular}




\section{Table 2 (continued)}

\begin{tabular}{|c|c|c|c|c|c|c|c|c|c|}
\hline & \multirow{2}{*}{ Item } & \multirow{2}{*}{ Source } & \multirow{2}{*}{$\begin{array}{l}\text { Corrected } \\
\text { Item- Total } \\
\text { Correlation }\end{array}$} & \multicolumn{6}{|c|}{ Factors loadings } \\
\hline & & & & PART & NOFI & SLACK & RISK & EMPHS & KNOW \\
\hline $\begin{array}{l}\text { Extracted } \\
\text { Variance }\end{array}$ & & Total variance $=53.786 \%$ & & 12.048 & 10.776 & 7.821 & 7.743 & 7.735 & 7.663 \\
\hline Eigen-value & & & & 5.767 & 2.739 & 2.092 & 1.797 & 1.659 & 1.543 \\
\hline $\begin{array}{l}\text { Cronbach } \\
\text { Alpha }\end{array}$ & & & & 0.822 & 0.796 & 0.715 & 0.719 & 0.698 & 0.635 \\
\hline
\end{tabular}

\subsection{Main study data collection}

The data for the main study are collected through a questionnaire survey. The research survey includes budgeting practitioners of enterprises which have a total annual revenue being greater than VND1 billion, located at HCMC, Vũng Tàu and Đà Nẵng province. 329 completed responses have been received at $47 \%$ of the effective response rate. After eliminating 42 invalid responses, the final sample is composed of 287 valid responses coming from 243 Vietnamese enterprises. The number of free parameters in the model is 29 . Thus, the sample size should be 145 ( $29 \times 5)$ according to Bollen's (1989) rule of five observations per free parameter estimated. Together with Hoelter's (1983) experiment rule that the sample size being greater than 200 for structural equation modeling, the size of 287 samples is thus appropriate according to Bollen's and Hoelter's experiment rules. The sample consists of 119 (49.0\%) manufacturing firms, 39 (16.1\%) trading firms and 85 (34.9\%) service firms. Informants in this survey have been working in many different functions, e.g. sales, production, treasury, accounting, internal control and planning departments. They are categorized into six groups in Table 3.

\subsection{Analytical method}

In order to test attributes and relationship among variables, structural equation modeling (SEM) is used to examine the theoretical model with the support of AMOS software. Before applying SEM analysis, all scales are re-assessed utilizing confirmatory factor analysis (CFA) to test the reliability of scales, discriminant validity and convergence of each factor. To evaluate the CFA and SEM model fit, the goodness-offit index (GFI), the comparative fit index (CFI) and the norm fit index (NFI) are used in conjunction with the Chi-square statistics and the degree of freedom (df) of the tested model. A model is fit when CMIN/df is smaller than 2; GFI, CFI and NFI are larger than 


\section{Table 3}

Number of respondents by positions and years in current position

\begin{tabular}{lcccc}
\hline \multirow{2}{*}{ Position } & \multicolumn{2}{c}{ Number of years in current position } & Total \\
\cline { 2 - 4 } & $1-3$ years & $4-6$ years & Over 6 years & \\
\hline General Manager & 17 & 15 & 15 & 47 \\
Deputy General Manager & 9 & 4 & 9 & 22 \\
Internal Control Manager & 3 & 3 & 0 & 6 \\
Chief Accountant & 28 & 29 & 25 & 82 \\
General Accountant & 23 & 21 & 10 & 54 \\
Head of Department & 18 & 27 & 10 & 55 \\
Deputy Head of Department & 10 & 7 & 4 & 21 \\
Total & 108 & 106 & 73 & 287 \\
\hline
\end{tabular}

0.9; RMSEA is smaller than 0.08 (Hair, Black, Babin, \& Anderson, 2010). At the last stage, a resampling bootstrap technique is used to evaluate confidence for maximum likelihood parameter estimates. It is carried out by repeatedly drawing samples from the original data that are gathered.

\section{Data analysis and findings}

\subsection{Data analysis}

Firstly, data is screened to be certainly appropriate with CFA and SEM analysis. Most of the univariate kurtoses and skewnesses are within the range of $[-1,1]$. Thus, maximum likelihood estimation is used (Muthen \& Kaplan, 1985). CFA model is then used to validate scales. The CFA result reveals an acceptable fit to data: Chi-square $=426.935$ $(\rho=.000) ; \mathrm{CMIN} / \mathrm{df}=1.286<2 ; \mathrm{CFI}=.961 ; \mathrm{GFI}=.910 ; \mathrm{TLI}=.956>.9$ and RMSEA $=.032<.080$. The factor loadings of all items are substantially high (the lowest loading is 0.54$)$, and all are significant $(\rho<.001)$. The correlation between constructs, together with their standard errors (Table 4), indicate that they are significantly different from unity and thus supporting the across-construct discriminant validity. Additionally, all the scales also have a high in composite reliability $\left(\rho_{c}>.60\right)$ and the average variance 
extracted $\left(\rho_{\mathrm{vc}}>.50\right)$ except for the scales measuring of EMPHS $\left(\rho_{\mathrm{vc}}=.35\right)$ and KNOW $\left(\rho_{\mathrm{vc}}=.48\right)$. In sum, these findings reveal that the scales used in this study are unidimensional and their convergent validity and reliability are achieved (Steenkamp \& Van Trijp, 1991).

\section{Table 4}

Correlation between constructs

\begin{tabular}{lllllll}
\hline Correlation & & & $\mathrm{r}$ & $\mathrm{s}$ & $\mathrm{cr}$ & $\mathrm{P}$ \\
\hline KNOW & $\leftrightarrow$ & PART & 0.355 & 0.055377 & 11.64750 & 0.00000 \\
KNOW & $\leftrightarrow$ & RISK & 0.301 & 0.056488 & 12.37435 & 0.00000 \\
RISK & $\leftrightarrow$ & PART & 0.375 & 0.054912 & 11.38180 & 0.00000 \\
EMPHS & $\leftrightarrow$ & PART & 0.359 & 0.055286 & 11.59422 & 0.00000 \\
SLACK & $\leftrightarrow$ & PART & 0.154 & 0.058528 & 14.45455 & 0.00000 \\
NOFI & $\leftrightarrow$ & PART & 0.355 & 0.055377 & 11.64750 & 0.00000 \\
EMPHS & $\leftrightarrow$ & RISK & 0.195 & 0.058098 & 13.85595 & 0.00000 \\
EMPHS & $\leftrightarrow$ & KNOW & 0.214 & 0.057863 & 13.58390 & 0.00000 \\
EMPHS & $\leftrightarrow$ & NOFI & 0.234 & 0.057590 & 13.30085 & 0.00000 \\
EMPHS & $\leftrightarrow$ & SLACK & 0.200 & 0.058038 & 13.78405 & 0.00000 \\
RISK & $\leftrightarrow$ & NOFI & 0.649 & 0.045065 & 7.788712 & 0.00000 \\
NOFI & $\leftrightarrow$ & SLACK & -0.110 & 0.058875 & 18.85337 & 0.00000 \\
KNOW & $\leftrightarrow$ & NOFI & 0.300 & 0.056506 & 12.38796 & 0.00000 \\
KNOW & $\leftrightarrow$ & SLACK & 0.026 & 0.059215 & 16.44857 & 0.00000 \\
RISK & $\leftrightarrow$ & SLACK & -0.046 & 0.059172 & 17.67722 & 0.00000 \\
\hline NOt & $\leftrightarrow$ & & & &
\end{tabular}

Note: r: correlation; se: standard error; cr: critical ratio; $\rho: \rho$-statistic

Regarding SEM results (Fig. 1), the proposed model's goodness of fit is assured with the following data: Chi-square $=447.723(\rho=.000) ; \mathrm{CMIN} / \mathrm{df}=1.325<2 ; \mathrm{CFI}=.955$; $\mathrm{GFI}=.904 ; \mathrm{TLI}=.950>.9$ and RMSEA $=.034<.080$. Heywood issue is absent because all standardized residuals are less than $|2.58|$. Table 5 showed the unstandardized estimates of the structural path and Fig. 2 present the standardized estimates. 


\section{Table 5}

Unstandardized structural paths in the model

\begin{tabular}{|c|c|c|c|c|c|c|c|}
\hline Hypothesis & Structura & aths & & ML & se & $\mathrm{cr}$ & $\mathrm{p}$ \\
\hline $\mathrm{H}_{1}$ & SLACK & $\leftarrow$ & PART & .137 & .062 & 2.210 & .027 \\
\hline $\mathrm{H}_{2}$ & EMPHS & $\leftarrow$ & RISK & .222 & .075 & 2.977 & .003 \\
\hline $\mathrm{H}_{3}$ & SLACK & $\leftarrow$ & EMPHS & .304 & .136 & 2.244 & .025 \\
\hline $\mathrm{H}_{4}$ & SLACK & $\leftarrow$ & KNOW & -.009 & .066 & -.131 & .896 \\
\hline $\mathrm{H}_{5}$ & NOFI & $\leftarrow$ & RISK & .844 & .109 & 7.769 & .000 \\
\hline $\mathrm{H}_{6}$ & SLACK & $\leftarrow$ & NOFI & -.232 & .086 & -2.695 & .007 \\
\hline
\end{tabular}

Note: ML: maximum likelihood; se: standard error; cr: critical ratio; $\rho$ : $\rho$-statistic

As discussed previously, the bootstrap procedure allows researchers to assess the stability of parameter estimates and thereby reporting their values with a greater degree of accuracy. In this paper, bootstrapping is performed on 500 bootstrap samples using the ML estimator to provide bias-corrected confidence intervals for each of the parameter bootstrap estimates at the level of $95 \%$ confidence. Table 6 compares the initial maximum likelihood unstandardized estimates and standard errors with those reported for the bootstrapped samples. The information which is provided in the Bias Column (BS) represented the difference between the bootstrap mean estimates and the original estimates. In this event, the mean estimates of the bootstrap samples are not significantly different from the original estimates and the values of bias are all very small, being reflected by the absolute of all critical ratios less than 2; therefore, it is concluded that all unstandardized estimates in Table 5 are reliable. 


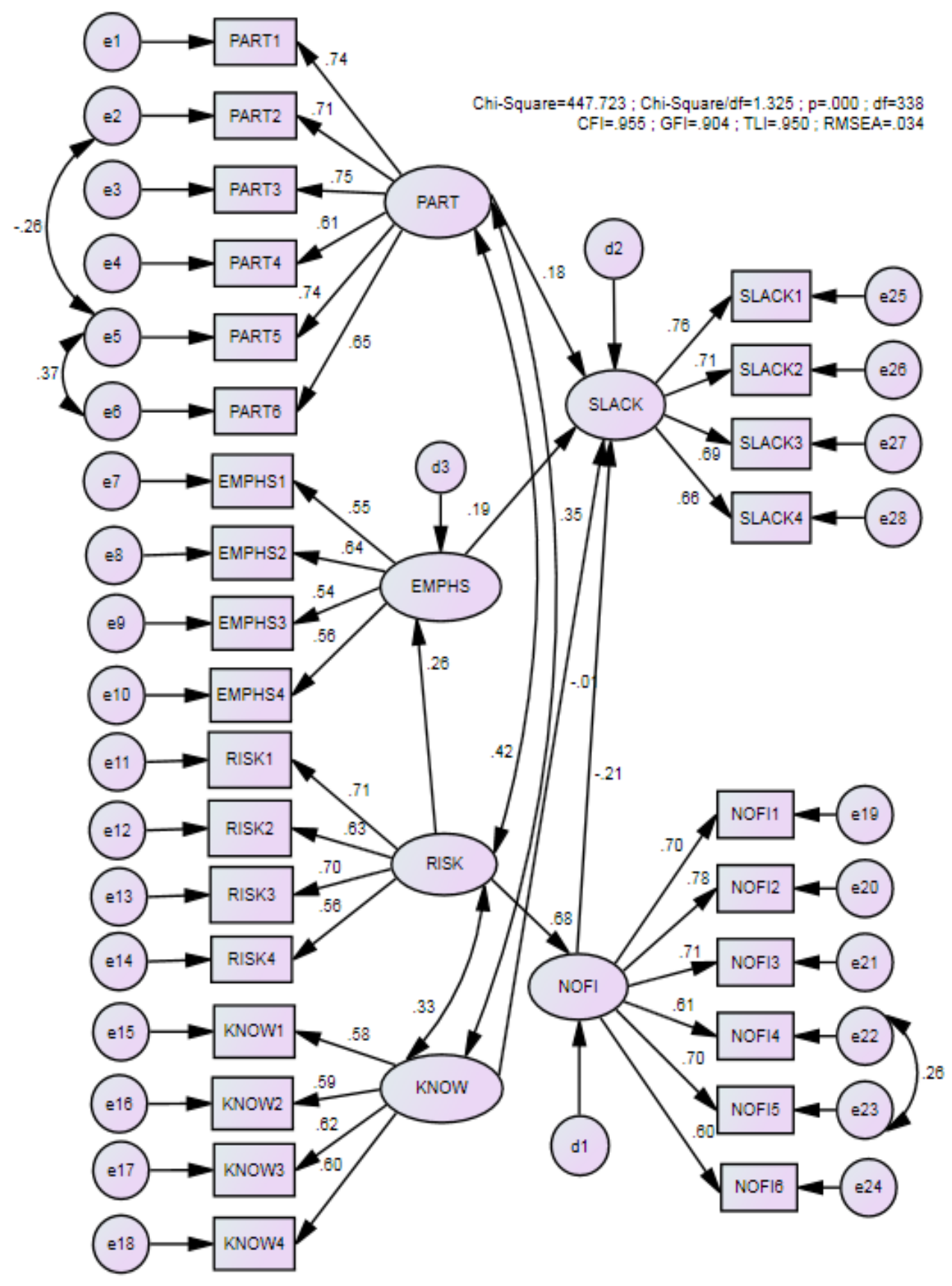

Fig. 2. Structural results (Standardized estimates) 


\section{Table 6}

Comparison between original estimates and bootstrap estimates

\begin{tabular}{|c|c|c|c|c|c|c|c|c|c|c|}
\hline \multicolumn{3}{|c|}{ Structural Path } & \multicolumn{2}{|c|}{$\begin{array}{c}\text { ML } \\
\text { estimates }\end{array}$} & \multicolumn{6}{|c|}{ Bootstrap estimates } \\
\hline & & & ML & SE & Mean & SE & $\mathrm{SE}(\mathrm{SE})$ & BS & $\mathrm{SE}(\mathrm{BS})$ & $\mathrm{CR}$ \\
\hline SLACK & $\leftarrow$ & PART & .137 & .062 & .137 & .075 & .002 & .000 & .003 & .000 \\
\hline EMPHS & $\leftarrow$ & RISK & .222 & .075 & .218 & .093 & .003 & -.004 & .004 & -1.00 \\
\hline SLACK & $\leftarrow$ & EMPHS & .304 & .136 & .310 & .165 & .005 & .006 & .007 & .857 \\
\hline SLACK & $\leftarrow$ & KNOW & -.009 & .066 & -.009 & .072 & .002 & .000 & .003 & .000 \\
\hline NOFI & $\leftarrow$ & RISK & .844 & .109 & .851 & .111 & .003 & .007 & .005 & 1.40 \\
\hline SLACK & $\leftarrow$ & NOFI & -.232 & .086 & -.238 & .088 & .003 & -.006 & .004 & -1.50 \\
\hline
\end{tabular}

\subsection{Findings}

The results of this study offer a number of implications for theory and practice. Consistent with Hypothesis 1, a positive relationship between budget participation and the propensity to create budget slack was found $(\beta=.137 ; \rho=.027<.05)$. This result is possibly explained that Vietnamese managers think budgetary slack is sometimes necessary to address the imbalance of power that is inherent in Vietnamese hierarchal organization. In addition, when there is any chance to establish indicators of performance assessment, lower-managers tend to create slack because it helps protect them from evaluation unfairness caused by imperfect performance measures or evaluation abuse by superiors. It was found a positive link between managers' awareness of business risks and the pressure to attain the budget goals $(\gamma=.222 ; \rho=.003<.05)$ and thus $\mathrm{H} 2$ was confirmed. Also, the result of Hypothesis 3 confirmed that when the attainment of budget goals was emphasized, it was normal for slack to be present in budget $(\beta=.304 ; \rho=.025<.05)$. These results were consistent with previous studies such as Duncan (1972); Onsi and Mohamed (1973); Dunk (1993); and Young (1985). However, to conclude that the relationships in $\mathrm{H}_{2}$ and $\mathrm{H}_{3}$ express ethical or unethical behavior is an arguable issue. Many managers argue that they do not view slack as a distortion, but as a means of protecting themselves from the downside potential of an uncertain future (Simons, 2000). Viewed this way, slack serves a function identical to that of the accepted managerial accounting practices of variance analysis and flexible 
budgeting; both of which are used to eliminate the effects on the performance measures of some uncontrollable factors (Simons, 2000). Particularly, most managers at all levels of Vietnamese enterprises regard slack as the behavioral norm. Indeed, in many Vietnamese companies, superiors actually want their subordinates to create slack because the superiors' targets are usually consolidation of their subordinates targets, so they enjoy the same reduction in risks and the increase in the expected values of their rewards as the slack creators.

From a conceptual standpoint, this paper contributed to managerial accounting literature by confirming $\mathrm{H}_{5}$ as a strongly positive link between risk awareness and the use of nonfinancial managerial accounting information $(\gamma=.844 ; \rho=.000<.05)$. There were some studies that checked the relationship between risk awareness and the level of using nonfinancial managerial accounting information such as the study by Hergert (1999); however a new negative correlation existing between this level and the propensity to create budgetary slack, in support of $\mathrm{H}_{6}(\beta=-.232 ; \rho=.007<.05)$, has never been examined before. These outcomes confirmed the role of nonfinancial managerial accounting information in turbulent business environment. This finding also revealed the use of nonfinancial information as an approach to reducing budgetary slack.

Regarding the influence of private knowledge $\mathrm{H}_{4}$, it was discovered to have a negative relationship with budgetary slack in contrast to the prediction that the length of time for a subordinate standing in a certain position in the organization might affect his or her level of private knowledge which in turn may be a contributing factor to budgetary slack creation tendencies. Strictly speaking, the negative relationship of Hypothesis 4 means that a subordinate in possession of better information regarding the activities undertaken in their responsibilities seems unwilling to create budgetary slack. The difference between hypothesis and result resulted from the majority of respondents, not from subordinates but from high-level managers (General Managers, Heads, Chief Accountants and Deputies) who had a high awareness of their profession or high commitment to the organization. Thus, they believed they had enough private knowledge within their scope of management to limit budgetary slack and to evaluate the potential areas of slack. However, this result was not statistically significant $(\beta=-.009 ; \rho=.896$ $>.05)$. 


\section{Managerial recommendations}

Based on the outcome of the fifth hypothesis in respect with managers' concerns with uncertainty and the affirmation of the role of nonfinancial managerial accounting information in the sixth hypothesis, two managerial solutions are suggested. Firstly, rolling budgets should be used as a substitute for the annual budget. A rolling budget is a budget continuously updated by adding further accounting periods when the earliest accounting period has expired (Sivabalan, Booth, Malmi \& Brown, 2009). Rolling budgets involve more frequent forecasting by companies in order to generate more accurate financial predictions when greater accuracy and reliability are required; therefore, they overcome many of the problems claimed for annual budgets, which have been the focus of critique to date. Secondly, organizing strategic management accounting is also highly recommended to increase the capacity of providing nonfinancial managerial accounting information to aid in strategic planning in a dynamic business environment. According to the definition of CIMA (2012), "Strategic management accounting is a form of managerial accounting in which emphasis is placed on information which relates to factor external to the entity, as well as nonfinancial information and internally generated information".

In this paper, the author only wishes to introduce to the readers the new techniques of managerial accounting in a modern business environment, e.g. rolling budget, strategic management accounting as the solutions of budgetary slack reduction, but how to implement these techniques should be presented in further research projects.

As can be seen in the second and the third hypotheses, using budgets as performance controls and reward system is the reason to create budgetary slack. Additionally, Sivabalan et al. (2009) investigated the role of budgets by survey of senior management accountants with a CPA qualification, to appear that:

"Two planning/control reasons (control of costs and board of director monitoring) were consistently more important than the staff evaluation and business unit evaluation reasons, while another two planning/control reasons (coordination of resources and formulation of action plans) were also more important than the staff evaluation reason for annual budgets."

Thus, it is recommended that managers should use budgets primarily for planning purposes instead of performance evaluation purposes in order to avoid the problems of budgetary slack. On the perspective of performance evaluation, managers should 
evaluate managerial performance using multiple indicators that take into account various factors such as a prevailing business environment and performance relative to competitors, especially the necessity of using financial information associated with nonfinancial managerial accounting information in performance assessment.

According to Tran's (2010) investigation, there are three ways in which a budget can be set in 118 listed companies in Vietnam, including the top-down approach (imposed budget), the bottom-up approach (participatory budget), and two-way approach. The majority of companies use the top-down approach to the budgeting process in Vietnam, presented in Table 7:

\section{Table 7}

Approaches to budgeting process in vietnamese listed companies

\begin{tabular}{lcc}
\hline Budgeting Process & Numbers of companies & Rate \\
\hline Top-down approach & 83 & $70.34 \%$ \\
Bottom up approach & 24 & $20.34 \%$ \\
Two-way approach & 11 & $9.32 \%$ \\
Total & 118 & $100 \%$ \\
\hline
\end{tabular}

Source: Tran (2010)

The top-down approach to budgeting is perhaps disadvantaged when Vietnamese business environment is presently more dynamic than the past. From a clear perception of the relationship between budget participation, private knowledge and budgetary slack in the first and the forth hypotheses, better approach for managers to reducing budgetary slack is a two-way process that involves themselves regularly in gaining understanding of what their subordinates are doing. Such involvement should not result in the managers dictating the decisions and actions of the subordinates, but their providing support, challenging in a motivational way, the assumptions subordinates make, and enhancing mutual learning about the operations. Regular interaction with subordinates allows managers to become knowledgeable about the operations and diminishes the ability of subordinates to create slack in their budgets.

Last but not least, the concrete solution to reduce budgetary slack is the change of control environment. That is, part of top management's responsibility is to promote commitment among the employees to set core values and norms. These values and norms 
describe what constitute acceptable and unacceptable behavior. Employees are trained in the code of conduct or credo to help them understand the behavior that is expected of them. Managers also have the responsibility to interact with and instruct their subordinates. These values and practices create a culture that discourages budgetary slack.

\section{Conclusion}

As a general conclusion, it is felt that the overall objective of the study has been met due to its display of the positive relationship between budget participation, budget emphasis and the propensity to create slack. The findings appear to indicate strong support of nonfinancial managerial accounting information for evaluation purposes besides budgetary targets. Furthermore, the findings also reflect managers' awareness of Vietnam's business environment, that is, in complex and turbulent environments, more companies perform different tasks toward the success of strategic planning in their use of nonfinancial managerial accounting information. In general, this study has contributed to the literature by showing that a range of factors attributed to managerial process leads to the propensity to create budgetary slack.

However, there are several shortcomings in this study which need to be acknowledged. Firstly, the outcomes of this study have not highlighted the relevance of the asymmetric information theory relevant to the degree of private knowledge held by subordinates, in relationship with the tendency of budgetary slack. Secondly, the survey data from 287 respondents in three main geographical areas may be noisy and require caution in terms of generalizing the results even though this number satisfies the experiment rules of the sample size. Thirdly, the survey conducted by the questionnaire often confronts the risk of self-selection bias, the attitude or the enthusiasm of the respondents. Despite these shortcomings, the findings provide avenues for research to explore alternative operational reasons of budgetary slack more comprehensively. Also, this study does not consider cultural or ethical reasons leading to budgetary slack in Vietnam. Future research into these reasons will contribute to a better understanding of slack reasons in organizations. On the other hand, budgeting theory to date has not addressed the influence of gender in a budgeting environment. Further research is needed to evaluate whether possible budgetary slack is influenced by variables demonstrating different impacts on male and female managers. Finally, in addition to introducing the 
new techniques to reduce budgetary slack, this paper does not demonstrate how to deploy these techniques in organizations. Thus, this aspect of research might also be broadened to include a study of how to organize internal operations applied to the techniques of strategic management accounting in order to limit the tendencies of budgetary slack

\section{References}

Bollen, K. A. (1989). Structural equations with latent variables. New York: Willey.

Chow, C., \& Stede, W. A. V. D. (2006). The use and usefulness of nonfinancial measures. Management Accounting Quarterly, 7(3), 1-8.

Chartered Institute of Management Accountants - CIMA. (2012). E3 - Enterprise strategy textbook. Fort Lauderdale, FL: Elsevier and Kaplan Publishing.

Cyert, D., \& March, S. M. (1963). The behavioral theory of the firm. Englewood Cliffs, NJ: Prentice Hall.

Dorestani, A. (2009). The association between nonfinancial key performance indicators and accounting and market-based performance, quality of earnings, and analysts' forecasts (Unpublished doctoral dissertation). University of Memphis, USA. Available from ProQuest Dissertations \& Thesis

Douglas, P. C., \& Wier, B. (2005). Cultural and ethical effects in budgeting systems: A comparison of U.S. and Chinese managers. Journal of Business Ethics, 60(2), 159-174. doi: http://dx.doi.org/10.1007/s10551-004-6711-z

Duncan, R. (1972). Characteristics of organizational environments and perceived environmental uncertainty. Administrative Science Quarterly, 17, 313-327.

Dunk, A. S. (1990). Budget participation, agreement on evaluation criteria and managerial performance: A research note. Accounting, Organizations and Society, 15, 171-178.

Dunk, A. S. (1993). The effect of budget emphasis and information asymmetry on the relation between budgetary participation and slack. The Accounting Review, 68(2), 400-410.

Gary, L. (1997). A Study of the influence of broadscope managerial accounting systems on the propensity to create slack (Unpublished doctoral dissertation). Louisiana Tech University, USA. Available from ProQuest Dissertations \& Thesis

Gélinas, P. (2007). Disclosure regulation, situational risk, situational ethics, and earnings management. Humanomics, 23(1), 58-65. doi: http://dx.doi.org/10.1108/08288660710725136

Hair, J. F., Black, W. C., Babin, B. J., \& Anderson, R. E. (2010). Multivariate data analysis: New Jersey: Pearson Academic. 
Hergert, J. K. (1999). Budget slack, private knowledge and managerial level (Unpublished doctoral dissertation). Nova Southeastern University, USA. Available from ProQuest Dissertations \& Thesis

Hoelter, J. W. (1983). The analysis of covariance structure: Goodness-of-fit indices. Sociological Methods \& Research, 11, 325-334.

Hoque, Z., \& Brosnan, P. (2007). Aligning industrial relations risk, budgetary participation, and budgeting measures of performance: Impact on managerial performance (SSRN Working paper). Rochester: Social Science Research Network.

Horngren, C. T., Datar, S. M., Foster, G., Rajan, M., \& Ittner, C. (2012). Cost accounting - A managerial emphasis (13th ed.). Upper Saddle River, NJ: Prentice Hall.

Jermias, J. (2011, October). Budgetary participation: The effects of information asymmetry, goal commitment, and role ambiguity on job satisfaction and performance. Paper presented at CAAA Annual Conference 2011, Toronto, Canada.

Kaplan, R. S., \& Norton, D. P. (2001). Transforming the balanced scorecard from performance measurement to strategic management: Part I. Accounting Horizons, 15(1), 87-104.

Kirby, A., Rechelstein, S., Sen, P., \& Paik, T. (1991). Participation, slack and budget-based performance evaluation. Journal of Accounting Research, 29(1), 109-128.

Lawrence, P. R., \& Lorsch, J. W. (1967). Organization and environment. Homewood, IL: Irwin.

Mason, R. B. (1985). The external environment's effect on management and strategy: A complexity theory approach. Management Decision, 45, 10-28.

Merchant, K. A. (1985). Budgeting and the propensity to create budgetary slack. Accounting, Organizations and Society, 10, 201-210.

Muthen, B., \& Kaplan, D. (1985). A comparison of some methodologies for the factor analysis of non-normal Likert variables. British Journal of Mathematical and Statistical Psychology, 38, 171180.

Nouri, H. (1996). The effect of organization commitment on the relation between budgetary participation and budgetary slack. Behavioral Research in Accounting, 8, 74-90.

Nunnally, J., \& Burnstein, I. H. (1994). Psychometric theory (3rd ed.): New York: McGraw-Hill.

Onsi, M. (1973). Factor analysis of behavioral variables affecting budgetary slack. The Accounting Review, 48(3), 535-548.

Pendergast, P. (1997). Budget padding: Is it a job for the finance police? Managerial Accounting, $75(10), 44-46$.

Schiff, M., \& Lewin, A. Y. (1970). The impact of budgets on people. The Accounting Review, 45(1), 259-268.

Simons, R. (2000). Performance measurement and control systems for implementing strategy. Englewood Cliffs. NJ: Prentice Hall. 
Sivabalan, P., Booth, P., Malmi, T., \& Brown, D. A. (2009). An exploratory study of operational reasons to budget. Accounting and Finance, 49, 849-871.

Srinivasan, D., Sayrak, A., \& Nagarajan, N. J. (2004). Executive compensation and nonfinancial information measures: A study of the incentive relevance of mandatory nonfinancial disclosure in the U.S airline industry (Working paper). University of Pittsburgh: Katz Graduate School of Business.

Steenkamp, J. B., \& Van Trijp, H. (1991). The use of LISREL in validating marketing construct. International Journal of Research in Marketing, 8(4), 283-299.

Stevens, D. E. (2002). The effects of reputation and ethics on budgetary slack. Journal of Management Accounting Research, 14, 153-171.

Tran, V. T. (2010). Designing and implementing the system of managerial responsibilities reports in Vietnamese listed companies (Unpublished doctoral dissertation). University of Economics HCMC, Vietnam.

Ueno, S., \& Sekaran, U. (1994). The influence of culture on budget control practices in the USA and Japan: An empirical study. Journal of International Business Studies, 23(4), 659-674.

Whyte, W. F. (1955). Money and motivation - An analysis of incentives in industry. New York: Harper and Brother.

Young, S. M. (1985). Participative budgeting: The effects of risk aversion and asymmetric information on budget slack. Journal of Accounting Research, 23(2), 829-842.

Yuen, D. (2007). Antecedents of budgetary participation: Enhancing employees' job performance. Managerial auditing journal, 22(5), 533-548. doi: http://dx.doi.org/10.1108/02686900710750793 